\title{
EXAMINATION ON THE STATE OF HEALTH REGARDING A PROTECTED SESSILE OAK STOCK

\author{
${ }^{1}$ P. Trenyik, ${ }^{2} \mathrm{O}:$ Szirmai, ${ }^{1}$ A. Barczi, ${ }^{1}$ J. Skutai, ${ }^{1}$ Sz. Czóbel
} \\ ${ }^{1}$ Department of Nature Conservation \& Landscape Ecology, Szent István University, Páter K. st. 1., H-2100 Gödöllő, Hungary \\ ${ }^{2}$ Botanical Garden of Szent István University, Páter u. 1., H-2100 Gödöllö, Hungary e-mail: trenyikpetra@gmail.com
}

\begin{abstract}
It can be observed in more and more fields of science that the results of other disciplines are utilised in order to achieve new results; it is true for nature conservation as well. Global climate change is to be considered as one of the most thoroughly studied topic; scientists pay special attention to the responses given by species and communities to climate change. In case of field examinations the accuracy of samplings and measurements is of key importance. Often solely estimated data is available which deteriorates the accuracy of the assessment. The health status of forests is usually determined by visual observations that imply errors due to human subjectivity. In this examination we surveyed the health status of a protected sessile oak stock within the Botanical Garden of Szent István University in Gödöllö by using not only conventional methods but also instrumental measurements. We have used FAKOPP 3D Acoustic Tomograph. It is an instrument developed in Hungary that is able to determine - in percentage - the extent of deterioration in tree trunks. The method of measurement is the following: this instrument measures the speed of sound propagation in the tree matter, since rotten and healthy tissues conduct sound differently. Prior to the examination we surmised that a predominantly healthy stock would be examined. Nevertheless, instrumental measurements proved that the trees of this stock are considerably decayed; therefore constant instrumental monitoring is required. We found that the extent of decomposition was the most significant in the lowest measurement level (i.e. $40 \mathrm{~cm}$ - Layer 1) and it steadily decreased in the higher regions.
\end{abstract}

Keywords: sessile oak, state of health, Botanical Garden, Fakopp

\section{INTRODUCTION}

Predictions of climate researchers stating that average temperatures are to be risen in every season in this century have become generally accepted [6]. This temperature elevation will presumably affect species and their ranges. In case of tree species the main influencing factor regarding the Northern limit of their range is temperature while the Southern or xeric limit is determined by the amount of precipitation. The temperature rise may have some positive effects on species as regards of Northern range since it enhances the process of succession due to the more favourable abiotic environment. As for the Southern limit, deteriorating water supply issues may cause the spreading of biotic diseases that reduces the competitiveness of certain species and biological associations [5].

Draught periods can be extremely hazardous since it is revealed that the forests' state of health deteriorates, causing thinning or even total destruction [1][3]. Some prognoses show the narrowing of optimal climate space for sessile oak; the extent of this process can involve 80 to 100 percent of all stocks by 2050 [2]. Thus it is necessary to examine the stress-tolerance ability and health state of sessile oak stocks in order to acquire information needed for the detection of changes [7].

Determining the state of health of individual trees is completed mainly by on-the-spot estimation of different parameters. These examinations try to eliminate errors originated from subjective and visual observations. Nevertheless, measured values also carry some degree of inaccuracy due to the method of estimation. So as to eliminate these inaccuracies instrumental measures have been implemented by using the FAKOPP 3D Acoustic Tomograph in areas covered by natural forests within the Botanical Garden of Szent István University. 


\section{MATERIALS AND METHODS}

We conducted our examinations on a protected sessile oak stock situated in the Botanical Garden of Szent István University. 20 sessile oaks were selected as subjects of study from the stock that is more than 100 years old. Measures were taken at five different heights $(40 \mathrm{~cm}, 80 \mathrm{~cm}, 120 \mathrm{~cm}, 160 \mathrm{~cm}$ and $200 \mathrm{~cm})$ regarding the selected specimens in order to determine their state of health. Besides data originated from FAKOPP 3D Acoustic Tomograph we also surveyed the general health status by using methods widely accepted in forestry practice, i.e. counting the chewed leaf area and the percentage of drying branches.

The FAKOPP system has been developed to examine living trees; the measured data provide evidences on the state of the inside of the trees as well as the extent of decomposition. This up-to-date method of tree examination measures the speed of sound propagation in trees. It creates a map of rotten tissues and holes within the trunk by detecting the speed of sound propagation. The theory behind this measurement is that sound propagates better in healthy tree tissue as compared to decaying material. The damage within the trunk can be determined by the decreasing propagation speed. The assessment has been made by computers, thus the process can be considered as computed tomography [4].

During measurement specifically developed detectors have been installed on the trees. The most possible detectors $(10 \mathrm{pcs})$ were applied in the whole process in order to get the most accurate results. Based on literature data these measurements are expedient to conduct when sap circulation is still intense in the plants. This period generally falls between March and mid-November. In 2014 autumn has been significantly warmer than the average; the vegetation period was elongated up to the end of November. Some of our measures have been implemented in between $10^{\text {th }}$ and $26^{\text {th }}$ of November while the rest were conducted in June 2015.

\section{RESULTS AND EVALUATION}

As a first step visual inspection has been completed. Based on this examination the general state of health of the selected stock has been acceptable, especially when considering the age of the trees. Both the leaf area and the trunks of the oaks suggested that the stock is healthy. The extent of branch drying has not been significant and the damage made by insects did not exceed the expectable amount, either (Tab. 1).

Table 1. Percentage referring to the state of health regarding the examined sessile oak specimens based on the observed parameters

\begin{tabular}{|c|c|c|c|}
\hline Sample trees & Rot (\%) & Leaf chewing (\%) & Dry branches (\%) \\
\hline $\mathbf{1}$ & 5.6 & 60 & 15 \\
\hline $\mathbf{2}$ & 11 & 60 & 5 \\
\hline $\mathbf{3}$ & 14.6 & 15 & 2 \\
\hline $\mathbf{4}$ & 45.6 & 20 & 15 \\
\hline $\mathbf{5}$ & 35.4 & 20 & 2 \\
\hline $\mathbf{6}$ & 13.2 & 25 & 5 \\
\hline $\mathbf{7}$ & 13.2 & 60 & 5 \\
\hline $\mathbf{8}$ & 2.8 & 50 & 7 \\
\hline $\mathbf{9}$ & 11.2 & 40 & 5 \\
\hline $\mathbf{1 0}$ & 10 & 35 & 3 \\
\hline $\mathbf{1 1}$ & 48.2 & 20 & 15 \\
\hline $\mathbf{1 2}$ & 5.6 & 25 & 5 \\
\hline $\mathbf{1 3}$ & 1.6 & 20 & 10 \\
\hline $\mathbf{1 4}$ & 14.4 & 60 & 2 \\
\hline $\mathbf{1 5}$ & 33.2 & 50 & 3 \\
\hline
\end{tabular}




\begin{tabular}{|c|c|c|c|}
$\mathbf{1 6}$ & 8.2 & 50 & 3 \\
\hline $\mathbf{1 7}$ & 18.4 & 30 & 5 \\
\hline $\mathbf{1 8}$ & 10.4 & 30 & 40 \\
\hline $\mathbf{1 9}$ & 20 & 45 & 25 \\
\hline $\mathbf{2 0}$ & 4.2 & 45 & 35 \\
\hline Average & $\mathbf{1 6 . 3 4}$ & $\mathbf{3 8}$ & $\mathbf{1 0 . 3 5}$ \\
\hline
\end{tabular}

A trend less palpable than expected has been outlined among the three factors suitable for monitoring the health status of trees. The extent of leaf chewing was the most balanced within the sampled trees since the extent of degradation caused by insects hardly varies within such small area. The average of leaf chewing was $38 \%$ that exceeds both the percentage of rotting and branch drying. Stronger correlation has been found between the latter two factors that can be explained by the fact that the decay of the trunk influences the sap circulation within the whole tree. This leads to unbalanced nutrient distribution causing the drying of certain parts of the individual plant. But branch drying is not only a result of inner decomposition: it can be initiated by certain weather anomalies. In our case sleets in December 2014 damaged the stock, too. Based on the results branch drying still showed a lower percentage than the average of rotting. The figures showed $10.35 \%$ and $16.34 \%$, respectively.

Average rot of tree trunks exceed $10 \%$ in more than half of the examined specimens that refers to a deteriorated state of health. The extent of rot showed differences regarding the five heights of measurement (Fig. 1). It can well be seen that the extent of decomposition was the most significant in the lowest measurement level (i.e. $40 \mathrm{~cm}$ - Layer 1) and it steadily decreased in the higher regions. The results are demonstrated in a stacked chart in order to visually accentuate the trend (Fig. 1).

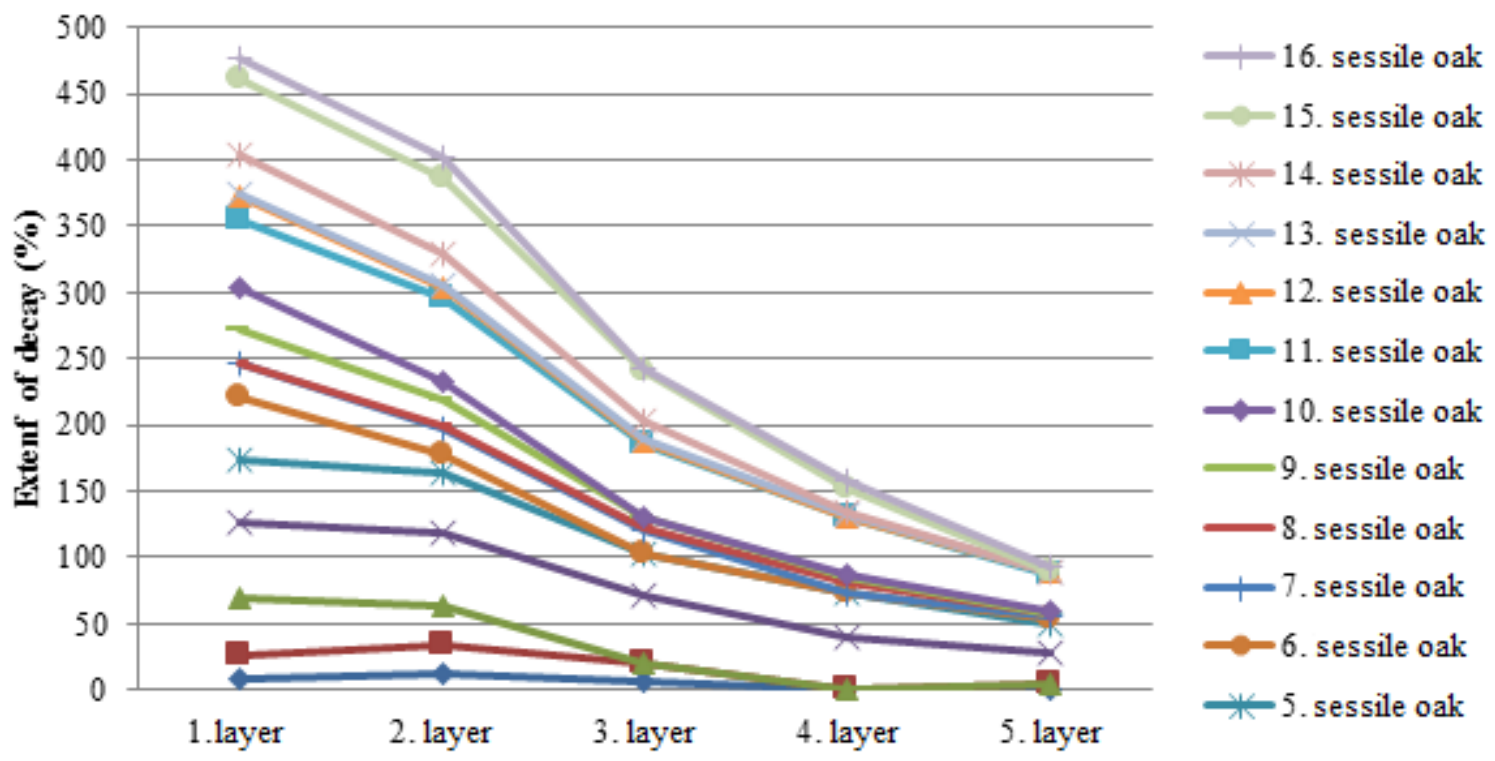

Figure 1. Comparison of the health status of examined specimens in different heights (layers)

Three oaks of significantly poor state of health (sample trees No. 4, 11 and 15) have been examined during the utilisation of FAKOPP. In all these cases the extent of decay exceeded $50 \%$ in the lower three layers. These specimens are threatened the most by falling, although the risk is present at those trees having a decay extent of 20 to $30 \%$ at the lower layers. These figures are especially high when considering the height of the trees $(20 \mathrm{~m}<)$ even if these oaks stand as a part of a stock. 
The old log can be responsible for the initiation of coppice decomposition. The instrumental measures also imply this explanation (Fig. 2 and 4).
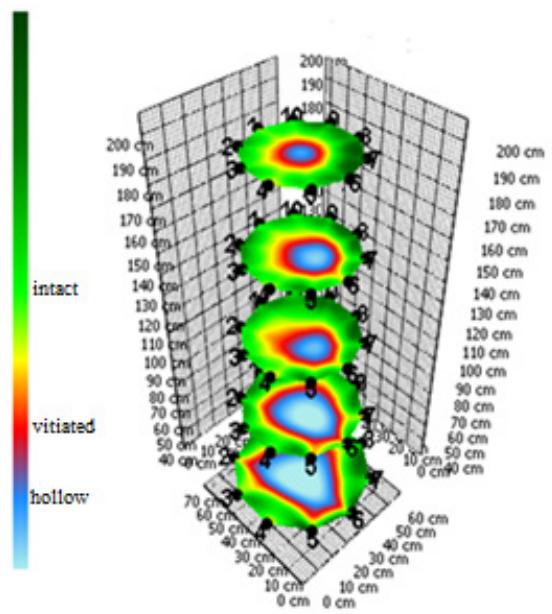

Figure 2. Cross-sectional view of an inwardly rotten sessile oak specimen measured in five different heights

In case of some specimens the decomposition has started outside, in the cortex area (Fig. 3). As for these trees presumably frost ribs are responsible for the decomposition instead of fungal diseases. Not even the presence of more saproxylophagus species leads inevitably to the deterioration of health status since these species consume only dead wood substance.

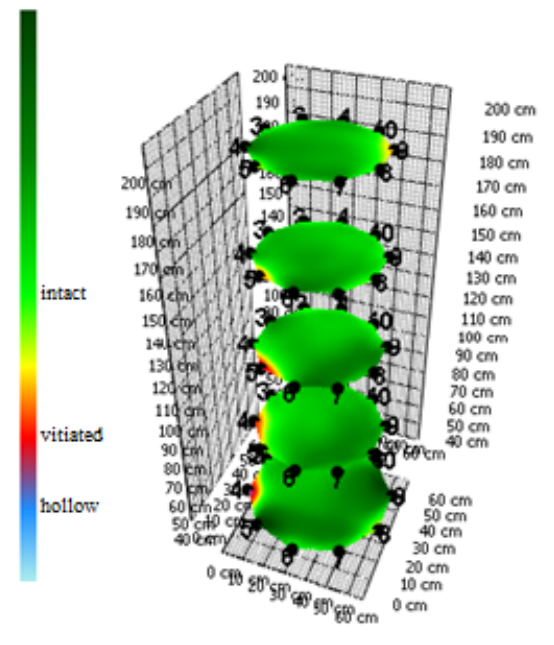

Figure 3. Outward deterioration of health in case of one examined sessile oak

Those sessile oaks had the worse state of health for which rotting had started its way not only from the inside but also from the outside. In this level of decomposition it is hard to determine where the rot originated from (Fig. 4 and 5). In these cases measurement by FAKOPP is more useful than visual inspection since an accurate picture is drawn about the state of the tree. Based on this result it is easier to decide whether some kind of intervention is necessary. 

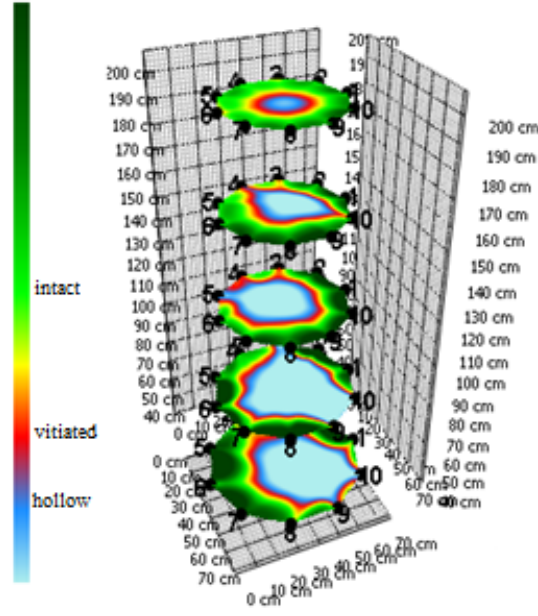

Figure 4. Extent of decay measured by FAKOPP in case of the severely deteriorated sessile oak No. 11

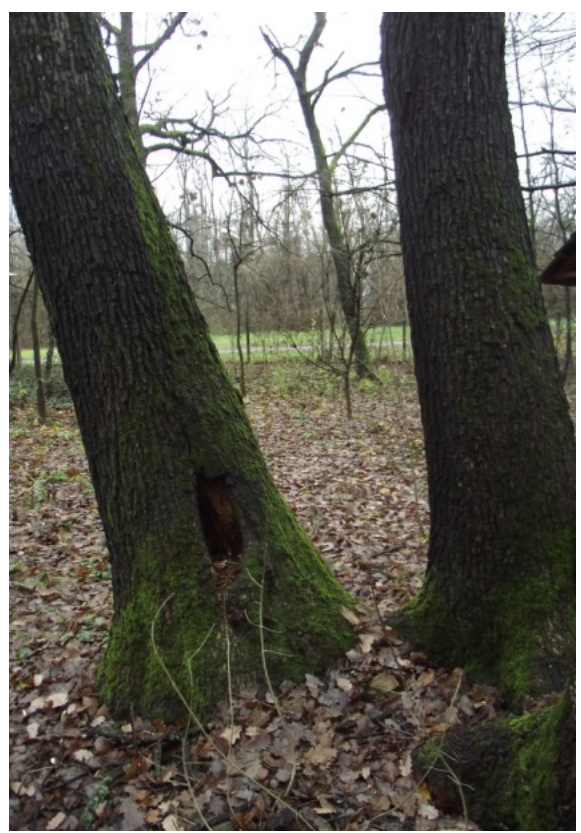

Figure 5. Photo of sessile oak No. 11 having decayed tissue both inside and in the cortex

\section{CONCLUSIONS}

By taking into account both the results of visual inspections and that of instrumental measurements it seems that the deteriorated health status of this stock is not a consequence of a disease or decaying organisms. By the data of the Botanical Garden it is revealed that this stock is a coppice forest. It can be a reason why this decomposition occurs. In case of all sampled trees the decay started at the root swelling which can also be a sign of natural ageing. With its average lifespan of 200 years sessile oak is a tree species with better longevity but this cycle is generally shorter in case of coppice wood. In forestry oak 
forests around 100 years old are usually cut. This means that the root system of trees in our coppice forest is approximately 200 years old and their lifespan draws near to its end.

Decrease of persistence in case of coppice trees can be caused by the fact that these specimens, due to their developed root systems, grow more intensely and develop wider annual rings compared to seedlings. Some decades later these attributes can accelerate the process of decomposition.

Monitoring the health status of forests plays an important role in climate change research. Many new or in some cases - more accurate data can be gained if the visual inspections are accompanied by instrumental measurements. On the one hand, errors originated from subjectivity and inaccurate estimations can be avoided. On the other hand, health state of tree stocks can be better defined. However, instrumental measurement itself cannot substitute visual inspection since the latter provide important additional information.

The utilisation of instrumental measurement is justified by the fact that not only a clearer picture is given on the extent of decay but its reason can also be revealed. In our case the coppice origin of the forest is responsible for the initiation of rotting. By knowing this the treatment for this protected stock can be determined while also considering the possible consequences as well.

Although this instrumental measurement is rather time-consuming compared to the traditional status check, it can be recommended to use in case of long-term researches dealing with the climate tolerance of biological associations, since the reactions of sample trees on biotic and abiotic damages can be better and accurately monitored.

\section{REFERENCES}

[1] Gy. Csóka, A. Koltay, A. Hirka, G. Janik, Az aszályosság hatása kocsánytalan tölgyeseink és bükköseink egészségi állapotára. KLÍMA-21 füzetek, 57, (2009), pp. 64-73.

[2] B. Czúcz, L. Gálhidy, Cs. Mátyás, A bükk és a kocsánytalan tölgy elterjedésének szárazsági határa. Erdészettudományi közlemények, 3, (2013), pp. :39-53.

[3] Gy. Csóka, A. Koltay, A. Hirka, G. Janik, Az aszályosság hatása kocsánytalan tölgyeseink és bükköseink egészségi állapotára. In: Mátyás Cs. és Vig P. (szerk.): Erdô és klíma V. kötet, Sopron, pp. 229-239, 2007

[4] P. Divós, F. Divós, Akusztikus tomográfia élő fák vizsgálatára. Faipar, 1, (2005)

[5] A. Hampe, R.J. Petit, Conserving biodiversity under climate change: the rear edge matters. Ecology Letters, 8, (2005), pp. 461-467.

[6] S. Solomon, D. Qin, M. Manning, Climate Change 2007: The Physical Science Basis. Contribution of Working Group I to the 4th Assessment Report of the IPCC, (2007) Cambridge University Press

[7] P. Trenyik , A. Barczi , Sz. Czóbel, Idős mag és sarj eredetü kocsánytalan tölgy dominálta állományok egészségi állapotának összehasonlító vizsgálata. p. 146 In: Padisák J., Liker A., Stenger-Kovács Cs. (szerk.): 10. Magyar Ökológus Kongresszus, Előadások és poszterek összefoglalói. Veszprém, 2015. augusztus 12-14., 165 p. 